\title{
Composite glandular-carcinoid tumour of the terminal ileum
}

\author{
N M Varghese, A M Zaitoun, S M Thomas, A Senapati, A Theodossi
}

\begin{abstract}
Aims-To investigate a female patient with a tumour mass of the terminal ileum, to define the nature of the tumour, and to correlate its morphology and behaviour with similar types of tumours of the large intestine and stomach.

Methods-Tissues obtained at colonoscopy, from hemicolectomy specimens, and from liver and peritoneal biopsy specimens were studied macroscopically, microscopically, histochemically, and immunohistochemically for epithelial membrane antigen (EMA), carcinoembryonic antigen (CEA), neuron specific enolase (NSE), and $\mathrm{S} 100$ protein.

Results-Macroscopic examination showed a tumour of the terminal ileum protruding into the caecum. Microscopically the tumour showed two components, one adenoma with moderate dysplasia and the other carcinoid tumour. The adenomatous component stained positively for EMA and CEA and negatively for NSE. The carcinoid component stained positively for NSE and negatively for EMA and CEA. Histochemically the carcinoid area was argyrophil positive and argentaffin negative. Only the carcinoid had metastasised, to the liver, peritoneum, and the lymph nodes, at the time of diagnosis.

Conclusion-The morphological, histochemical, and immunohistochemical findings confirm the diagnosis of a composite adenoma-carcinoid tumour of the terminal ileum.
\end{abstract}

$(F$ Clin Pathol 1994;47:427-429)

Department of Gastroenterology N M Varghese A Theodossi

Department of Pathology

A M Zaitoun

$S M$ Thomas

Department of

Surgery, Mayday

Healthcare NHS Trust

A Senapati

Correspondence to:

Dr A M Zaitoun,

Department of

Histopathology, Mayday

Healthcare NHS Trust,

Mayday Road, Thornton

Mayday Road, Thornton
Heath, Surrey CR7 7YE

Heath, Surrey CR7 7YE

3 November 1993
Adenomas develop only rarely in the ileum. The gross and histological appearances of these tumours resemble those arising in the large bowel mucosa. ${ }^{1}$ The ileum is also a common site for carcinoid tumours that may arise from endocrine or mucosal progenitor stem cells. These tumours invade and involve the muscle wall leading, in time, to fibrosis and buckling of the small bowel wall.

The occurrence of a typical carcinoid tumour admixed with an adenoma/adenocarcinoma, is a very rare phenomenon of the gastrointestinal tract and only a few cases of these composite tumours have so far been described, occurring in the colon and rectum..$^{2-4}$ Various histogenetic theories on the origin of composite tumours have been sug- gested but no single one is universally accepted. ${ }^{235-7}$

We describe the pathological findings of a composite glandular-carcinoid tumour of the terminal ileum, in which the glandular component of the composite tumour was benign. As far as we are aware, this is the first such report of an association in the small intestine.

\section{Case report}

A 76 year old Caucasian woman was seen in the gastroenterology clinic with a three month history of rectal bleeding. There was no history of facial flushing, diarrhoea, or alteration of bowel habits. There was no family history of gastrointestinal cancer.

Physical examination and laboratory investigations were within normal limits. A barium enema showed sigmoid diverticular disease only, but colonoscopy showed a single $4 \mathrm{~cm}$ polypoid tumour in the caecum. A biopsy specimen of the tumour showed separate components of adenoma and carcinoid and the diagnosis of composite glandular and carcinoid tumour was suggested. At laparotomy the tumour was found to arise in the terminal ileum and to prolapse through the ileocaecal valve into the caecum. Two small secondary tumours in the liver and a few peritoneal deposits were also seen. As the tumour had infiltrated the mesentery overlying the terminal ileum, a right hemicolectomy was performed with removal of $60 \mathrm{~cm}$ of the terminal ileum. The postoperative course was uneventful and the patient was referred for chemotherapy.

\section{Pathological examination}

Specimens from the initial biopsy of the tumour, the tumour mass, liver, and peritoneal deposits were fixed in $10 \%$ buffered formaldehyde and processed routinely in paraffin wax. Blocks were cut at $5 \mu \mathrm{m}$ thickness and stained with haematoxylin and eosin, diastase/periodic acid-Schiff, Grimelius (argyrophil), and Fontana-Masson (argentaffin) stains. Representative blocks from the primary tumour and metastatic deposits were also selected for immunohistochemical analysis and $4 \mu \mathrm{m}$ sections were stained for carcinoembryonic antigen (CEA), epithelial membrane antigen (EMA), neuron specific enolase (NSE), and S100 protein by the avidinbiotin-peroxidase complex technique. Positive and negative controls were used to verify the specificity of the immunoreagents. All the 
primary antibodies were obtained from Dako Limited, High Wycombe, Buckinghamshire, England.

\section{Results}

The surgical specimen consisted of $60 \mathrm{~cm}$ of terminal ileum, together with appendix, caecum, and a portion of the ascending colon. On section, a pedunculated polypoid tumour $(4 \times 3.5 \times 2.3 \mathrm{~cm})$ of the terminal ileum was seen, arising proximal to the ileocaecal valve and protruding through it into the caecum. The cut sections of the tumour looked light

Figure 1 (A) staining for NSE showing positive staining for the carcinoid area and negative staining for the adenomatous area

(immunoperoxidase stain); (B) immunoperoxidase staining for $C E A$ showing positive staining for the adenomatous area and negative staining for the carcinoid area

(immunoperoxidase stain).
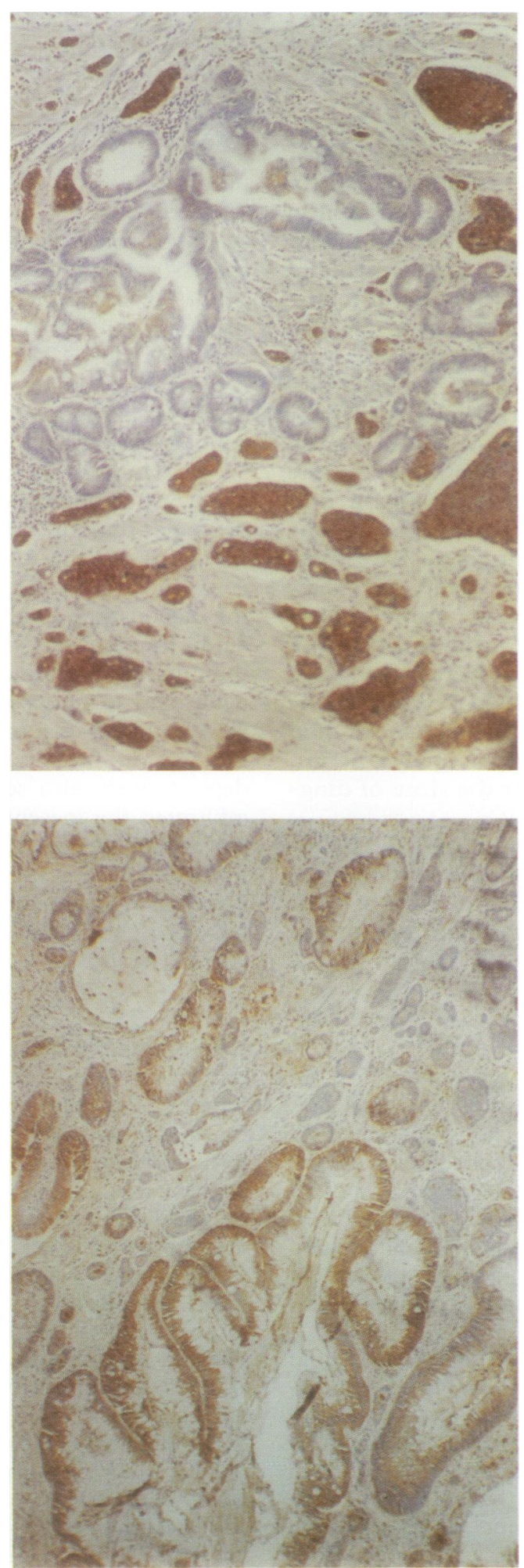

brown in colour. Histological examination showed a tubular adenoma with most of the central area occupied by carcinoid tumour cells. The adenomatous component was peripheral and showed moderate dysplasia in some glands. The carcinoid component was argyrophil positive and argentaffin negative. Immunohistochemical staining in the carcinoid areas was positive for neuron specific enolase (fig 1A) and negative for carcinoembryonic antigen. Immunohistochemical staining of the adenomatous areas was positive for CEA (fig 1B) and negative for NSE. Transition zones between the carcinoid and adenomatous components were seen. Carcinoid tumour had invaded the polyp stalk, muscle layers, serosal and subserosal tissues, and tumour thrombi was seen in adjacent blood vessels and lymphatics. Both lines of resection were free of tumour. Sections from the appendix, caecum, and ascending colon were normal. Sections from the liver, peritoneal nodules, and two of $13 \mathrm{lymph}$ nodes examined showed metastatic carcinoid tumour of similar morphology and immunoreactivity to the ileal tumour.

\section{Discussion}

Composite adenoma/adenocarcinoma-carcinoid tumours of the gastrointestinal tract have aroused considerable interest. ${ }^{235}$ There are no reports of their occurrence in the small bowel. The feature of a benign glandular component in a composite tumour has only been previously reported on two cases. ${ }^{3}$

The clinical diagnosis of a polypoid tumour in the present case was made at colonoscopy. The negative barium enema may be explained by intermittent prolapse of the ileal polyp into the caecum. This clinical presentation is similar to "pure" ileal carcinoid tumours, which usually present with small intestinal obstruction or intussusception.

The case discussed is unique in that it is a true adenoma of the terminal ileum exhibiting moderate dysplasia, which is extremely rare in this part of the bowel. ${ }^{1}$ It is also unique for its morphological spectrum of adenomatous and carcinoid elements, which appear as separate components yet have occasional transitional zones between them. The morphology of metastatic elements in composite glandular endocrine cell tumours are similar to those of the primary tumour. ${ }^{5-10}$ Only the carcinoid element of this tumour behaved in a malignant fashion and a similar pattern of metastasis has been reported by Lyss et al. ${ }^{11}$ The histochemical and immunohistochemical findings confirm the diagnosis of the carcinoid elements within the primary tumour and in the metastatic deposits. The term composite glandular-carcinoid tumour is therefore an appropriate name for this neoplasm in our case. This is also supported by the absence of endocrine cell hyperplasia within the adenomatous component of this tumour and also within the adjacent normal mucosa of the caecum, terminal ileum, and appendix.

The advent of immunohistochemistry and 
Morphological spectrum and clinical behaviour with metastases of composite glandular-endocrine cell tumours of the gastrointestinal tract

\begin{tabular}{|c|c|c|c|c|c|c|}
\hline \multirow[b]{2}{*}{ Tumour and site } & \multirow[b]{2}{*}{ Description and components } & \multirow[b]{2}{*}{ Behaviour } & \multirow[b]{2}{*}{ Site of metastases } & \multicolumn{2}{|c|}{ Metastatic components } & \multirow[b]{2}{*}{ Reference } \\
\hline & & & & Morphology & Carcinoid only & \\
\hline $\begin{array}{l}\text { Stem cell carcinoma } \\
\text { of the rectum and } \\
\text { colon }\end{array}$ & $\begin{array}{l}\text { Undifferentiated tumour cells with } \\
\text { features of both carcinoid and squamous } \\
\text { cell carcinoma }\end{array}$ & $\begin{array}{l}\text { Highly } \\
\text { malignant }\end{array}$ & $\begin{array}{l}\text { Liver, lymph } \\
\text { nodes and ovary }\end{array}$ & As primary & & 10 \\
\hline $\begin{array}{l}\text { Small cell } \\
\text { undifferentiated } \\
\text { carcinoma of colon }\end{array}$ & $\begin{array}{l}\text { Undifferentiated cells showing } \\
\text { features of both carcinoma and } \\
\text { carcinoid }\end{array}$ & $\begin{array}{l}\text { Highly } \\
\text { malignant }\end{array}$ & $\begin{array}{l}\text { Liver and lymph } \\
\text { nodes }\end{array}$ & As primary & & 8 \\
\hline $\begin{array}{l}\text { Undifferentiated } \\
\text { (stem cell) } \\
\text { carcinoma of the colon }\end{array}$ & $\begin{array}{l}\text { Undifferentiated malignant cells } \\
\text { admixed with foci of } \\
\text { neuroendocrine and squamous cells }\end{array}$ & $\begin{array}{l}\text { Highly } \\
\text { malignant }\end{array}$ & $\begin{array}{l}\text { Liver and lymph } \\
\text { nodes }\end{array}$ & As primary & & 9 \\
\hline $\begin{array}{l}\text { Undifferentiated } \\
\text { carcinoma of the colon }\end{array}$ & $\begin{array}{l}\text { Undifferentiated small cell tumour } \\
\text { with features of both carcinoid and } \\
\text { squamous cell carcinoma }\end{array}$ & Malignant & $\begin{array}{l}\text { Liver, adrenal } \\
\text { gland, lymph } \\
\text { nodes }\end{array}$ & As primary & & 5 \\
\hline $\begin{array}{l}\text { Composite carcinoid } \\
\text {-adenocarcinoma of } \\
\text { stomach }\end{array}$ & $\begin{array}{l}\text { Two separate components of } \\
\text { carcinoid and adenocarcinoma } \\
\text { invading the wall of the stomach } \\
\text { No transitional zones between the } \\
\text { two components }\end{array}$ & Malignant & No metastases & & & 7 \\
\hline $\begin{array}{l}\text { Composite argantiffinoma- } \\
\text { adenocarcinoma of the } \\
\text { colon }\end{array}$ & $\begin{array}{l}\text { Two separate components of } \\
\text { carcinoid and adenocarcinoma with } \\
\text { transitional zones }\end{array}$ & Malignant & $\begin{array}{l}\text { Liver and } \\
\text { lymphatic }\end{array}$ & As primary & & 6 \\
\hline $\begin{array}{l}\text { Adenocarcinoid } \\
\text { tumour of the colon } \\
\text { arising in pre-existing } \\
\text { ulcerative colitis }\end{array}$ & $\begin{array}{l}\text { Microinvasive carcinoma with signet } \\
\text { ring cell }\end{array}$ & Malignant & $\begin{array}{l}\text { Lymph nodes, } \\
\text { peritoneal and } \\
\text { mesenteric } \\
\text { deposits }\end{array}$ & & Carcinoid & 11 \\
\hline $\begin{array}{l}\text { Mixed adenocarcinoma } \\
\text { carcinoid of the large } \\
\text { bowel in pre-existing } \\
\text { Crohn's disease }\end{array}$ & $\begin{array}{l}\text { Two separate elements of } \\
\text { adenocarcinoma with carcinoid }\end{array}$ & Malignant & No metastases & & & 4 \\
\hline $\begin{array}{l}\text { Composite glandular } \\
\text { carcinoid tumour of } \\
\text { the terminal ileum }\end{array}$ & $\begin{array}{l}\text { Two separate elements of benign } \\
\text { adenoma with malignant } \\
\text { carcinoid and transitional zones }\end{array}$ & Malignant & $\begin{array}{l}\text { Liver, peritoneal } \\
\text { deposits, and } \\
\text { regional lymph } \\
\text { nodes }\end{array}$ & & Carcinoid & Current case \\
\hline $\begin{array}{l}\text { Composite tumour } \\
\text { of the rectum }\end{array}$ & $\begin{array}{l}\text { Tubulovillous adenoma with } \\
\text { separate carcinoid element } \\
\text { invading the stalk }\end{array}$ & $\begin{array}{l}\text { Locally } \\
\text { malignant }\end{array}$ & No metastases & & & 2 \\
\hline $\begin{array}{l}\text { Composite glandular } \\
\text { - carcinoid of the } \\
\text { colon and rectum }\end{array}$ & $\begin{array}{l}\text { Two separate elements of tubulovillous } \\
\text { adenoma with carcinoid } \\
\text { including transitional zones }\end{array}$ & Benign & No metastases & & & 3 \\
\hline
\end{tabular}

electron microscopy has, by supplementing routine methods, aided the diagnosis, morphological subtyping, and thereby the prognosis of mixed glandular-endocrine tumours. In general, composite glandular-carcinoid tumours have a poorer prognosis than pure carcinoids. ${ }^{10}$

A review of reports in English on composite glandular-endocrine cell tumours, helps to elucidate the morphological features and the clinical behaviour of these tumours (table). These vary from benign tumours ${ }^{3}$ to locally invasive $^{2}$ and highly malignant metastasising tumours. ${ }^{8-10}$ It should be noted, however, that all cases of malignant composite tumours so far described that have metastasised, have been those in which the carcinoid has been associated with adenocarcinoma, unlike the present case where it is associated with an adenoma.

The histogenesis of composite adenocarcinoma-carcinoid tumours has not been fully explained. The collision tumour theory suggests that the composite tumour represents two different carcinomas that grew together. ${ }^{2}$ In the common origin theory, composite tumours arise from bidirectional differentiation of a common stem cell. ${ }^{3611}$ The presence of transitional zones where the adenocarcinoma and carcinoid areas merge together is thought to favour the common origin theory. ${ }^{3}$

Such transitional zones were clearly seen in our case. As emphasised in earlier studies, ${ }^{3}$ further documentation is required to achieve a more complete clinical and pathological understanding of these enigmatic tumours.

We thank Dr I C Talbot, Department of Pathology, St Mark's Hospital, London, for reviewing both the biopsy of the tumour and the manuscript.

1 Perzin $\mathrm{KH}$, Bridge MF. Adenomas of small intestine-A clinicopathologic review of 51 cases and a study of thei relationship to carcinoma. Cancer 1981;48:799-819.

2 Mori K, Shinya H, Kalisman M. A composite tumour in tubulovillous adenoma of the rectum. Dis Colon Rectum 1978;21:506-9.

3 Moyana TN, Qizilbash AH, Murphy F. Composite glandular-carcinoid tumours of the colon and rectum. Report of two cases. Am f Surg Pathol 1988;12:607-11.

4 Hock YL, Scott KWM, Grace RH. Mixed adenocarcinoma/carcinoid tumour of the large bowel in a patient with Crohn's disease. 7 Clin Pathol 1993;46:183-5.

5 Petrelli M, Tetangco E, Reid JD. Carcinoma of the colon with undifferentiated carcinoid and squamous cell features. Am $₹$ Clin Pathol 1981;75:581-4.

6 Bates HR, Belter LF. Composite carcinoid tumour (argentaffinoma-adenocarcinoma) of the colon: report of two cases. Dis Colon Rectum 1967;10:467-70.

7 Caruso ML, Pilato FP, D'Adda T, Baggi MT, Fucci L Valentini AM, et al. Composite carcinoid-adenocarcinoma of the stomach associated with multiple gastric carcinoids and non-antral gastric atrophy. Cancer 1989;64:1534-9.

8 Damjanov I, Amenta PS, Bosman FT. Undifferentiated carcinoma of the colon containing exocrine neuroendocrine and squamous cells. Virchows Arch $A$ Pathol Anat 1983;401:57-66.

9 Mills SE, Allen MS, Cohen AR. Small cell undifferentiated carcinoma of the colon: a clinicopathological study of ated carcinoma of the colon: a clinicopathological study of five cases and their association with

10 Palvio DHB, Sorensen FB, Klove-Mogensen M. Stem cell carcinoma of the colon and rectum. Report of two cases and review of the literature. Dis Colon Rectum 1985;28:440-5.

11 Lyss AP, Thompson J, Glick JH. Adenocarcinoid tumour of the colon arising in pre-existing ulcerative colitis. Cancer 1981;48:833-9. 